\title{
An Unusual Foreign Body in The Larynx: A Live Leech in The Larynx
}

\author{
Larinkste Nadir Görülen Bir Yabancı Cisim: Larinkste Canlı Bir Sülük
}

\author{
Çiğdem Fırat Koca', Mehmet Turan Çiçek², Erhan Kayıkçıoğlu²
}

${ }^{1}$ Malatya State Hospital, Malatya; ${ }^{2}$ Kabta State Hospital, Adryaman

\begin{abstract}
Leeches are blood-sucking hermaphroditic parasites that vary in color, length, and shape. They usually reside in fresh water streams and lakes. Swimming in streams or drinking infested water are the major contamination ways. When the contaminated water is drunk, the leech may adhere to anywhere along the upper aerodigestive tract. They may present in the nasal cavity, oropharynx, hypopharynx, larynx, trachea and esophagus. Indirect laryngoscopy is the best way to make a definitive diagnosis and direct laryngoscopy is the procedure of choice to remove the leeches. This case is about a 37 year-old man who was referred to our otolaryngology clinic with a complaint of blood stained salina, one day after stream water drinking. At the laryngeal face of the epiglottis, we determined an alive brown colored foreign body and under indirect laryngoscopy the foreign body was removed by the forceps and diagnosed as a leech. In this case report we wanted to share our experiment of a rare case of living leech at the laringeal region with a short review of the literature.
\end{abstract}

Key words: leech; foreign body; larynx

\section{ÖZET}

Sülükler çeșitli renklerde, boyda ve șekilde olabilen kan emen hermafrodit parazitlerdir. Çoğunlukla su kaynakları ve göllerde yașarlar. Bu sularda yüzmek veya enfekte suları içmek bașlıca kontaminasyon yollarıdır. Enfekte su içildiği zaman sülükler üst hava ve sindirim sisteminin herhangi bir yerine tutunabilir. Nazal kavitede, orofarenkste, hipofarenkste, larinkste, trakea veya özefagusta bulunabilir. Kesin tanı için en iyi yol indirekt laringoskopi ve sülüklerin çıkarılmasında tercih edilecek en iyi yöntem direkt laringoskopidir. Bu olgu sunumu kliniğimize kaynak suyu içtikten bir gün sonra kanlı tükrük șikayeti olan 37 yașındaki erkek hasta hakkındadır. Indirekt laringoskopi eșliğinde epiglot laringeal yüzünde kahverengi canlı bir yabancı cisim izledik ve cisim indirekt laringoskopi altında forceps yardımı ile çıkarıldı ve yabancı cisim canlı bir sülüktü. Bu olgu sunumunda laringeal alanda nadir görüen canlı bir sülük vakasındaki tecrübemizi literatür eșliğinde tartıșarak paylașmak istedik.

Anahtar kelimeler: sülük; yabancı cisim; larinks

Uzm. Dr. Cï̆dem Firat Koca, Malatya Devlet Hastanesi Kulak Burun Boğaz Kliniği,Malatya, Türkiye, Tel.05302239624Email.cifirat@hotmail.com Geliş Taribi: 14.11.2015 • Kabul Taribi: 05.11.2016

\section{Introduction}

Leeches are parasites that live on occasional blood sucking by attaching to fish, amphibians, and mammals. They use anterior suckers consisting of the jaws and teeth to attach to their host's mucous membrane to feed ${ }^{1}$.

Leech bodies are composed of 34 segments. Externally, leeches tend to have a brown and red striped design on an olive colored background. These organisms have two suckers, one at each end, called the anterior and posterior sucker. The posterior is mainly used for leverage while the anterior sucker, consisting of the jawand teeth, is where the feeding takes place. Leech saliva contains a number of compounds which assist in its feeding. An anaesthetic limits the sensations felt by the host. A vasodilator causes the blood vessels near the leech to become dilated, and thus provides the leech with a better supply bleeding as much as $150 \mathrm{cc}$ of bleed for up to 48 hours. Leech saliva contains a complex protein called hirudin which is a highly effective anticoagulant ${ }^{2}$.

\section{Case Report}

A 37-year-old man was referred to Adiyaman Kahta State Hospital Otolaryngology Head and Neck Surgery Department with a complaint of blood stained salina. One day after drinking stream water the patient developed blood stained salina; he reported odynophagia and dysphagia. He was examined thorougly and in detailed history he remembered that the symptoms had begun after washing his mouth and face with stream water and had drunk the same water. On examination throat was normal without any sign of bleeding. Indirect laryngoscopic examination we revealed a live leech in laryngeal region (Figure 1). 

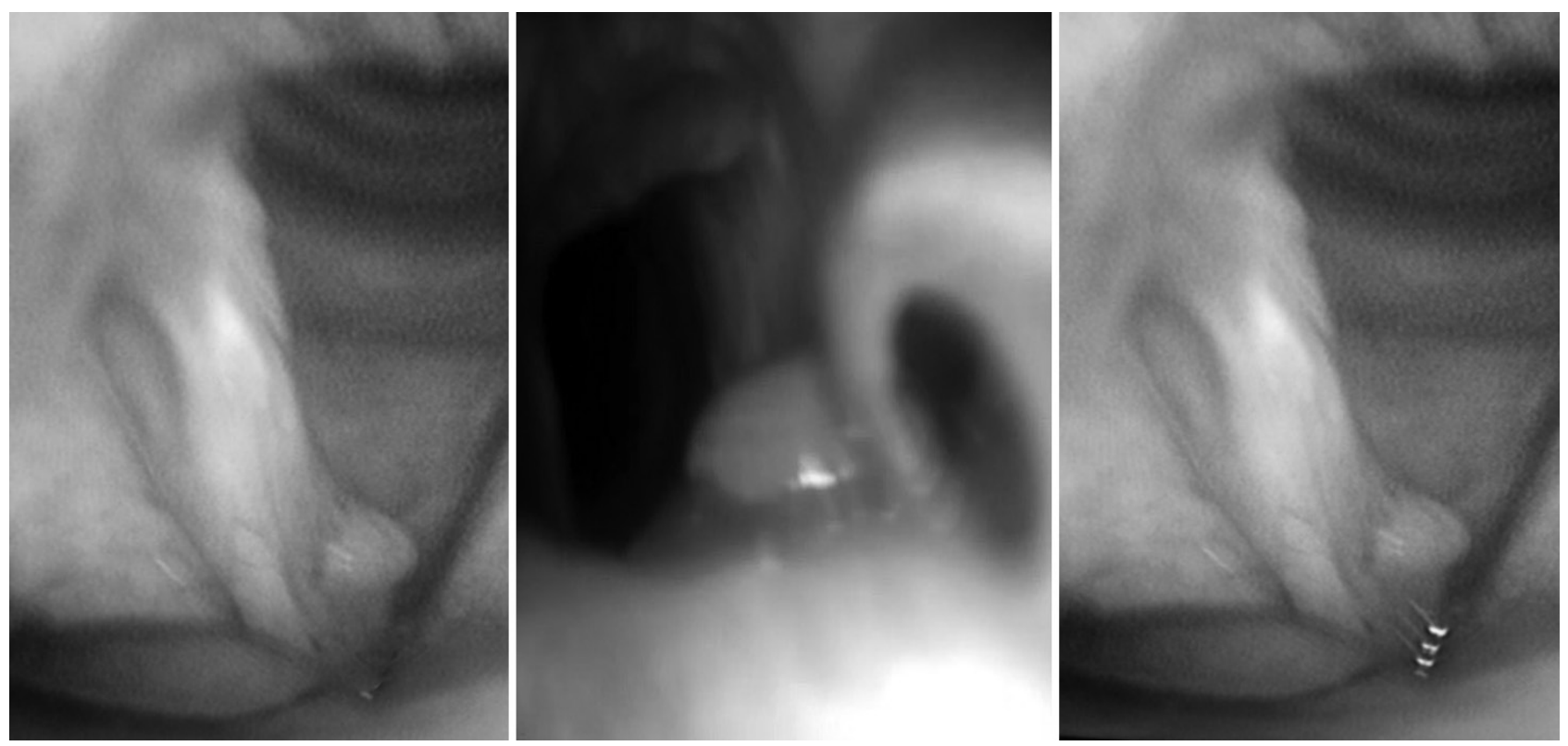

Figure 1. Indirect laryngoscopic view of the live leech.

We had maintained the optimal conditions against the possibility of any complication before the removing process was carried out. Located in laryngeal region was a live leech with its sucking head stuck to the laryngeal face of epiglottis. The leech was gently grasped with foreign body forceps (Figure 1) and we carefully waited until the leech loosened its grasp by this way it could be removed undamaged and intact with its full length of about $2.5 \mathrm{~cm}$ (Figure 2).

There was no problem before and after the process. The patient's symptoms were all relieved and there was no bleeding in the extraction site.

\section{Discussion}

Leeches are blood-sucking hermaphroditic worms that vary in color, length, and shape ${ }^{3}$. Approximately 600 leech species have been identified up to now, but only about 15 different types are used in medicine ${ }^{4}$. Leeches belong to the phylum annelida of the class Hirudinea. Leeches have different shapes from elongated and cylindrical to broad or ovoid. Their color may be black, brightly colored. They have muscular suckers at both their anterior and posterior ends. Their length varies from $5 \mathrm{~mm}$ to $45 \mathrm{~cm}^{5,6}$.

They usually reside in fresh-water streams and lakes. Leeches are the rare live foreign bodies in the upper aerodigestive system. The first report of leeches lodged in the upper airway system was reported by the Persian physician Rasis ${ }^{3}$. Leech infestations among humans is very rare and can be seen especially in urban areas. The people who live in urban areas think that mountain waters may be benefical. The usage of this waters may cause some elusive parasitic infestations; like leech infestations ${ }^{7}$. Swimming in streams or drinking infested water are the contamination ways of the leech infestation. When the contaminated water is drunk the leech

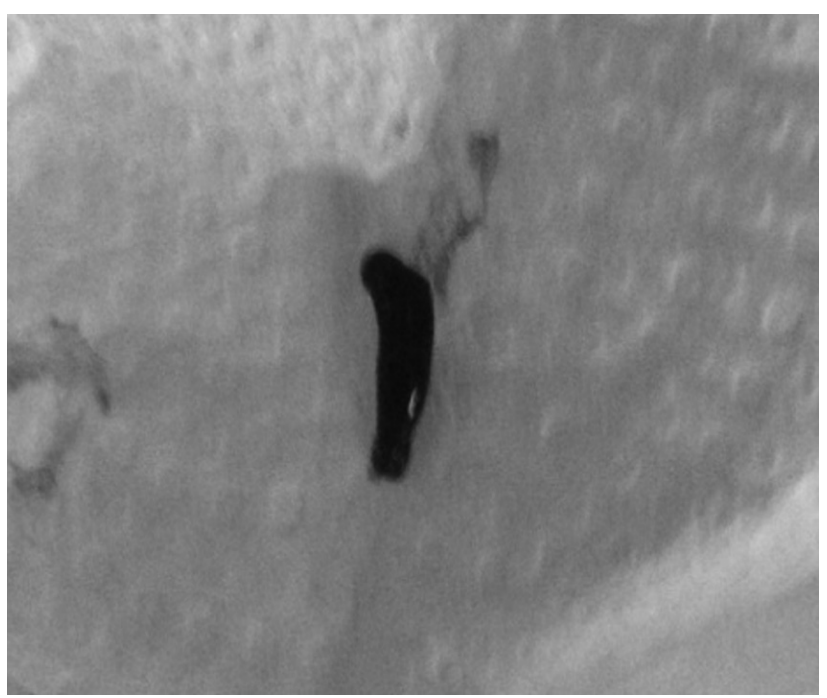

Figure 2. The leech obtained from the patient. 
may adhere to anywhere along the upper aerodigestive tract. They may present in the nasal cavity, oropharynx, hypopharynx, larynx, trachea and esophagus. Leeches adhere the mucous membrane and ingest blood. For this reason, aquatic leeches may be dangerous, and may cause severe anemia which may require blood transfusion. This situation may be fatal in especially children ${ }^{4}$.

Leeches can secrete an anticoagulant enzyme named hirudin, which inhibits coagulation of the blood. They may cause epistaxis, haematemesis, hemoptysis or even anemia according to the exact site of the infestation. Leeches can ingest blood up to approximately nine times their own body weight ${ }^{8}$. Leeches affix firmly to the mucous membrane by its anterior sucker, and irrigation hypertonic sodiumchloride solution, glycemine phervice, and lidocaine have been reported to detach a leech from the mucosa. These methods should be performed with great caution in the respiratory tract to avoid broncospasm, mucosal chemical injure and even suffocation $^{1,5}$. A foreign body in the respiratory tract should be considered an emergency condition that requires immediate measures against the possibility of hypoxia and even death. Internal attachment of leeches in different areas of human body such as pharynx, larynx, bronchi, nose and rectum have been reported in the literature. Agin et al. reported nasopharyngeal leech infestation with epistaxis and hematemesis 9

Ghimine et al. ${ }^{10}$ reported a unilateral nostril epistaxis caused by leech infestation. Siddiquie and colleagues ${ }^{11}$ reported severe anemia requiring packed cell transfusion and nasal infection caused by leech. Bilgen ${ }^{8}$ reported leech caused recurrent epistaxis during 4 months. Kaygusuz et al. ${ }^{12}$ reported four patients with laryngeal leech infestation presenting as stridor and dyspnea ${ }^{13}$. Leeches attach the tissues strongly with their strong suckers and for this reason removal of a leech requires special care ${ }^{4}$.

The best way to remove the leech from the aerodigestive tract is direct laryngoscopic examination under general anesthesia. It is very important to remove the leech gentle and cautiously, because it is slippery and can be rupture easily. Blunt jaws forceps are preferable. The other important point is removing all parts of the leech's body. If the head of the leech remains, it could be result in continued bleeding, because the suckers contain hirudin. The hirudin is an anticoagulant enzyme. Lidocaine causes relaxation of the head suckers and may be useful ${ }^{3}$. Soft tissue radiograph of the neck may reveal a foreign body but is not specific for leech. Direct laryngoscopy is gold standart to maintain an emergency diagnosis and removal ${ }^{2}$.

\section{Conclusion}

It should be taken into consideration that the presence of a live leech in the respiratory tract, in patients with complaint of hemoptysis, hoarseness and respiratory distress of unknown origin who have a history of contact with untreated water.

\section{References}

1. Zhang P, Zhang R, Zou J, Zhu T. A rare case report of tracheal leech infestation in a 40-year-old woman. Int J Clin Exp Med 2014;7(10):3599-601.

2. Mekonnen D. Leech infestation: the unusual cause of upper airway obstruction. Ethiop J Health Sci 2013;23(1):65-8.

3. Rajati M, Irani S, Khadivi E, Bakhshaee M. An unusual cause of dysphonia with hemoptysis: a laryngeal live leech. Iran J Otorhinolaryngol 2014;26(76):181-3.

4. Oğhan F, Güvey A, Özkıııs M, Gülcan E, Oropharyngeal leech infestation and therapeutic options. Turkiye Parazitol Derg 2010;34(4):200-2.

5. Askari N, Eshaghian A. Otorrhagia bleeding due to leech bite. Adv Biomed Res 2012;1:15.

6. Fooanant S, Puntasri W, Manorot M, Niwasabutra S. A leech in the nasal cavity: Case report. Chiang Mai Med Bull 2006; $45: 27-30$.

7. Uzun B, Korucuk E, Sezak NB, Özdemir R, Demirci M. A case of leech infestation mimicking upper respiratory tract infection. Turkiye Parazitol Derg 2011;35(3):169-71.

8. Bilgen C, Karci B, Uluoz U. A nasopharyngeal mass: leech in the nasopharynx. Int J Pediatr Otorhinolaryngol 2002;64:73-76.

9. Agin H, Ayhan FY, Gulfidan G, Cevik D, Derebasi H. Severe anemia due to the pharyngeal leech Lim-natis nilotica in a child. Turkiye parazitol derg 2008;32:247-8.

10. Ghimire A, Acharya A. Unusual cause of unilateral epistaxis: nasal leech infestation. JNMA J Nepal Med Assoc 2008;47:38-40.

11. Siddiqui TS, Qureshi I, Mufti TS. Nasal leech--a rare cause of severe anemia. J Ayub Med Coll Abbottabad 2005;17:82-3.

12. Kaygusuz I, Yalcin S, Keles E. Leeches in the larynx. Eur Arc Otorhinolaryngol 2001;258:455-7.

13. Vegari S, Ghaffarlou M, Davarimajd L, Golzari SE. Globus Sensation Due to a Mobile Foreign Body in a 41-year-old Female. J Cardiovasc Thorac Res 2012;4(1):29-30. 